\title{
Clusters of inflammation in COVID-19: descriptive analysis and prognosis on more than 15,000 patients from the Spanish SEMI-COVID-19 Registry
}

\author{
Manuel Rubio-Rivas ${ }^{1}$ - José María Mora-Luján ${ }^{1} \cdot$ Francesc Formiga ${ }^{1} \cdot$ Miguel Ángel Corrales González ${ }^{2}$ - María del \\ Mar García Andreu ${ }^{3}$. Víctor Moreno-Torres ${ }^{4}$. Gema María García García ${ }^{5}$. José N Alcalá Pedrajas ${ }^{6} \cdot$ Ramon Boixeda $^{7}$. \\ Leticia Pérez-Lluna $^{8}$ - Begoña Cortés-Rodríguez ${ }^{9} \cdot$ Carmen Mella-Pérez $^{10} \cdot$ María de la Sierra Navas Alcántara $^{11}$. \\ Manuel Lorenzo López Reboiro ${ }^{12}$. Verónica Alfaro-Lara ${ }^{13}$. Santiago Pérez-Martín ${ }^{14}$. José Ángel Martín-Oterino ${ }^{15}$. \\ Anyuli Gracia Gutiérrez ${ }^{16}$. Anabel Martín-Urda Díez-Canseco ${ }^{17}$. Pere Comas Casanova ${ }^{18}$. Cristina Pérez García ${ }^{19}$. \\ José F Varona ${ }^{20,21}$ • Ricardo Gómez-Huelgas ${ }^{22,23}$ • Juan-Miguel Antón-Santos ${ }^{24}$. Carlos Lumbreras-Bermejo ${ }^{25}$ on \\ behalf of the SEMI-COVID-19 Network
}

Received: 12 August 2021 / Accepted: 30 December 2021 / Published online: 2 March 2022

(c) The Author(s), under exclusive licence to Società Italiana di Medicina Interna (SIMI) 2022

\begin{abstract}
Uncontrolled inflammation following COVID-19 infection is an important characteristic of the most seriously ill patients. The present study aims to describe the clusters of inflammation in COVID-19 and to analyze their prognostic role. This is a retrospective observational study including 15,691 patients with a high degree of inflammation. They were included in the Spanish SEMI-COVID-19 registry from March 1, 2020 to May 1, 2021. The primary outcome was in-hospital mortality. Hierarchical cluster analysis identified 7 clusters. $\mathrm{C} 1$ is characterized by lymphopenia, $\mathrm{C} 2$ by elevated ferritin, and $\mathrm{C} 3$ by elevated LDH. C4 is characterized by lymphopenia plus elevated CRP and LDH and frequently also ferritin. C5 is defined by elevated CRP, and C6 by elevated ferritin and D-dimer, and frequently also elevated CRP and LDH. Finally, C7 is characterized by an elevated D-dimer. The clusters with the highest in-hospital mortality were C4, C6, and C7 (17.4\% vs. $18 \%$ vs. $15.6 \%$ vs. $36.8 \%$ vs. $17.5 \%$ vs. $39.3 \%$ vs. $26.4 \%$ ). Inflammation clusters were found as independent factors for inhospital mortality. In detail and, having cluster $\mathrm{C} 1$ as reference, the model revealed a worse prognosis for all other clusters: $\mathrm{C} 2(\mathrm{OR}=1.30, p=0.001), \mathrm{C} 3(\mathrm{OR}=1.14, p=0.178), \mathrm{C} 4(\mathrm{OR}=2.28, p<0.001), \mathrm{C} 5(\mathrm{OR}=1.07, p=0.479), \mathrm{C} 6(\mathrm{OR}=2.29$, $p<0.001)$, and $\mathrm{C} 7(\mathrm{OR}=1.28, p=0.001)$. We identified 7 groups based on the presence of lymphopenia, elevated CRP, LDH, ferritin, and D-dimer at the time of hospital admission for COVID-19. Clusters C4 (lymphopenia + LDH + CRP), C6 (ferritin + D-dimer), and C7 (D-dimer) had the worst prognosis in terms of in-hospital mortality.
\end{abstract}

Keywords Coronavirus $\cdot$ COVID-19 $\cdot$ Cluster analysis $\cdot$ Inflammation $\cdot$ Prognosis $\cdot$ Mortality

\section{Introduction}

As of May 2021, COVID-19 has infected more than 170 million people worldwide and caused the death of more than 3.5 million people [1]. Death is largely due to the inflammatory escalation or host cytokine storm secondary to SARS-CoV-2

A complete list of the SEMI-COVID-19 Network members is provided in the Appendix.

Manuel Rubio-Rivas

mrubio@bellvitgehospital.cat

Extended author information available on the last page of the article infection [2]. This inflammatory response has clearly analytically identifiable components [3]. Clinically, most individual patients showed the changes of lymphocyte counts, D-dimer, interleukin-6 (IL-6), C-reactive protein (CRP), ferritin, $\mathrm{LDH}$, etc. Why some patients become more inflamed than others is not known for certain but it is possible that there is a genetic background that facilitates this. Among those patients who present with this exaggerated inflammatory response, different degrees of inflammation have been described that predict the short-term future of these patients [4]. However, this inflammation is far from being homogeneous in all patients. From these studies, we know that the more parameters of analytical inflammation the worse the 
prognosis. The next step is to find out if some parameters have more prognostic value than others. In fact, in clinical practice, we see how some patients start their analytical inflammation in one way and others in another. This suggests different pathways and perhaps also different prognoses.

The present study aims to describe the different clusters or differentiated groups of inflammation in COVID-19 and to analyze their prognostic role.

\section{Materials and methods}

\section{Study design, patient selection, and data collection}

The present study is a retrospective observational study of consecutive patients included in the Spanish SEMICOVID-19 Registry, created by the Spanish Society of Internal Medicine (SEMI). This is a multicenter, nationwide registry with over 150 hospitals registered so far. From March 1, 2020 to May 1, 2021, 21,962 hospitalized patients were included in the Registry. The characteristics of this registry have been detailed in previous reports [5]. In brief, all included patients were diagnosed by polymerase chain reaction (PCR) test or rapid antigenic test for SARS-CoV-2 taken from a nasopharyngeal sample, sputum, or bronchoalveolar lavage. The collection of data from each patient in terms of sociodemographic data, comorbidities, laboratory data, treatments, and outcomes was verified by the principal investigator of each center through the review of clinical records. All participating centers in the register received confirmation from the relevant Ethics Committees, including Bellvitge University Hospital (PR 128/20). Informed consent was obtained from the subjects.

The inclusion criteria were all patients in the registry with a community (non-nosocomial) SARS-CoV-2 infection and belonging to the high-risk category of inflammation according to our previous report and based on the lab test on admission [4]. This category of high risk is based on the decrease in the lymphocyte count $101.5 \mathrm{mg} / \mathrm{L}$, lactate dehydrogenase $(\mathrm{LDH})>394 \mathrm{U} / \mathrm{L}$, ferritin $>1359.9 \mathrm{mcg} / \mathrm{L}$, and D-dimer $>1580 \mathrm{ng} / \mathrm{mL}$.

The treatments received were in accordance with the medical guidelines available at the time of the pandemic [6-11]. In the absence of clinical evidence of any of the treatments at the initial time of the pandemic, their use was allowed off-label.

\section{Outcomes definition}

The primary outcome of the study was in-hospital mortality. Secondary outcomes were the requirement of high-flow nasal cannula (HFNC), non-invasive mechanical ventilation
(NIMV), invasive mechanical ventilation (IMV), or ICU admission.

\section{Statistical analysis}

Multiple imputations of missing data were performed. Categorical variables were expressed as absolute numbers and percentages. Continuous variables are expressed as mean plus standard deviation (SD) in the case of parametric distribution or median [IQR] in the case of nonparametric distribution. Differences between groups were assessed using the Chi-square test for categorical variables and ANOVA or Kruskal-Wallis test as appropriate for continuous variables. $p$ values $<0.05$ indicated statistical significance.

The cluster analysis was performed by ascendant hierarchical clustering on the 5 laboratory variables previously selected using Ward's minimum variance method with Euclidean squared distance [12]. Results are graphically depicted by a dendrogram. The number of clusters was estimated by the kmeans method. The cluster analysis model was included in a binary logistic regression, taking in-hospital mortality as the dependent variable. We introduced in the multivariate model those variables with a $p$ value $<0.10$ in the univariate model. In-hospital mortality between clusters was depicted by the Kaplan-Meier curves with their logarithmic range test (event: death; censored data: hospital discharge).

Statistical analysis was performed by IBM SPSS Statistics for Windows, Version 26.0. Armonk, NY, USA: IBM Corp.

\section{Results}

\section{General baseline data between groups}

From March 1, 2020 to May 1, 2021, 20,641 patients admitted for non-nosocomial COVID-19 were included in the SEMI-COVID-19 registry. Of these, 15,691 fell into the high-risk category for inflammation according to the laboratory tests at admission and were therefore included in the present study (Figure S1).

Hierarchical cluster analysis identified 7 clearly differentiated clusters (C1-C7) (Fig. 1). The baseline characteristics of the 7 clusters are shown in Table 1. It is noteworthy that $\mathrm{C} 1$ patients attend the hospital earlier from the onset. $\mathrm{C} 2$ and $\mathrm{C} 3$ patients have a lower Charlson index. $\mathrm{C} 4$ patients are older and predominantly male and have more comorbidity (mainly hypertension and dyslipidemia). C5 patients have more comorbidity (mainly hypertension, dyslipidemia and diabetes mellitus). Patients in groups C6 and 


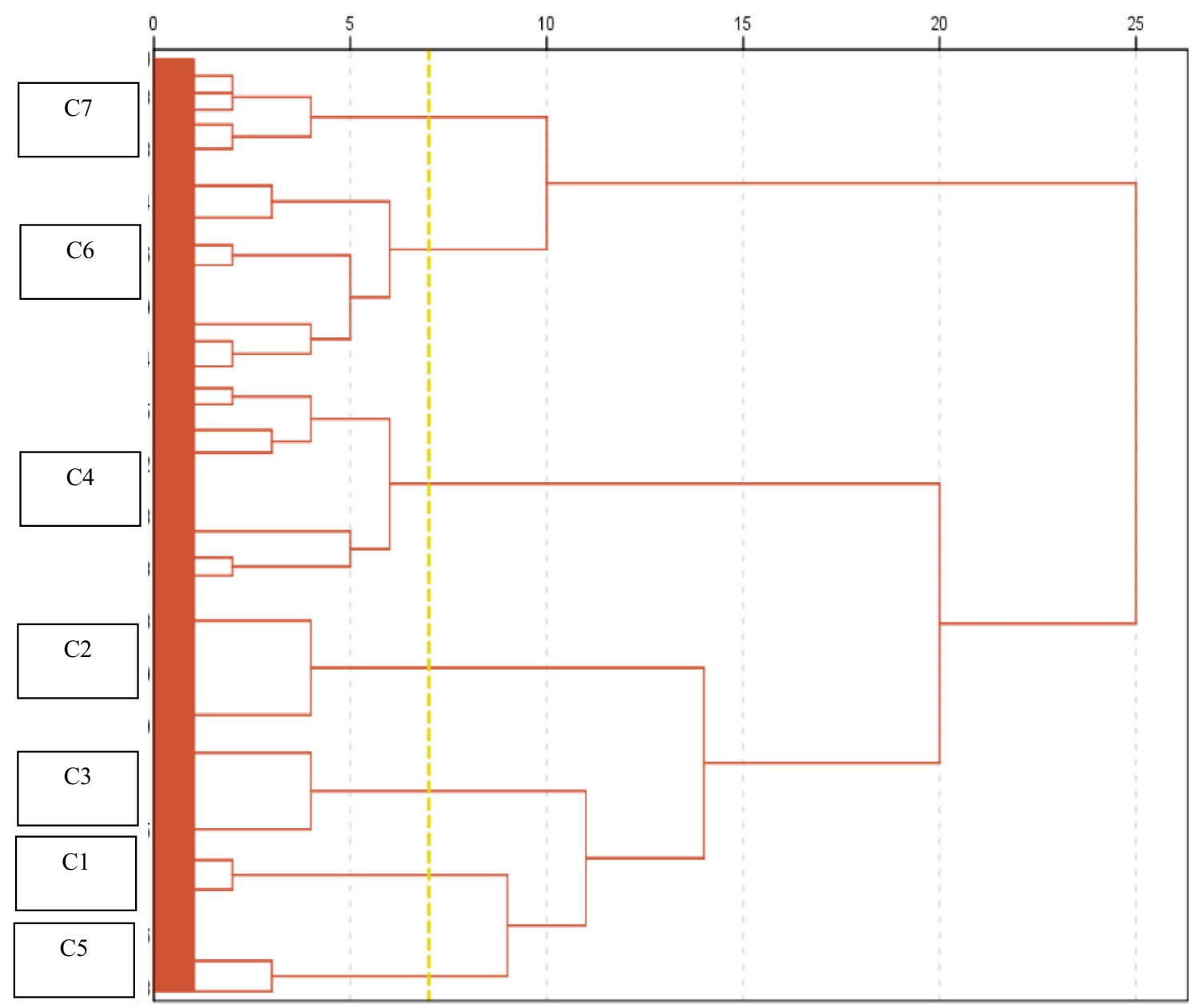

Fig. 1 Dendrogram. Clusters based on analytical inflammatory parameters upon admission. Cluster $\mathrm{C} 1$ is characterized by the presence of lymphopenia, cluster $\mathrm{C} 2$ by elevated ferritin, and $\mathrm{C} 3$ by elevated LDH. Cluster C4 is characterized by lymphopenia plus ele-

C7 are older and have more dependency and comorbidity (mainly hypertension, dyslipidemia and diabetes mellitus).

Symptoms at the time of hospital admission are listed in Table S1. In particular, group C1 presents more frequently with a headache. $\mathrm{C} 2$ and $\mathrm{C} 3$ present more frequently with headaches, arthromyalgia, sore throat, cough, diarrhea, anosmia, and ageusia. $\mathrm{C} 4$ patients present more frequently with cough, tachypnea, and less diarrhea. Cluster C5 most frequently presents with headache, arthromyalgia, cough, anosmia, and ageusia. Clusters C6 and C7 present less frequently with fever and cough.

\section{Laboratory tests between groups}

Table $\mathrm{S} 2$ shows the inflammatory analytical parameters presented by each of the clusters. According to the most relevant analytical feature in each group, we can define cluster $\mathrm{C} 1$ by the presence of lymphopenia, cluster $\mathrm{C} 2$ by elevated vated CRP and LDH and frequently also elevated ferritin. Cluster C5 is defined by elevated CRP, and cluster C6 by elevated ferritin and D-dimer and frequently also elevated CRP and LDH. Finally, cluster C7 is characterized by elevated D-dimer

ferritin, and $\mathrm{C} 3$ by elevated LDH. Cluster C4 is characterized by lymphopenia plus elevated CRP and LDH and often also elevated ferritin. Cluster C5 is defined by elevated CRP, and cluster $\mathrm{C} 6$ by elevated ferritin and D-dimer and often also elevated CRP and LDH. Finally, group C7 is characterized by elevated D-dimer. Figure 2 shows the distribution of each of the inflammatory parameters in each cluster.

It should be noted that cluster $\mathrm{C} 4$ is the cluster with the lowest $\mathrm{PaO} 2 / \mathrm{FiO} 2$ on admission. This fact possibly shows a greater inflammatory component and greater evolution to ARDS.

\section{Treatments during admission}

Table S3 shows the treatments received during admission. Logically, the clusters with a greater analytical inflammatory component (C4) received corticosteroids and tocilizumab more frequently. On the other hand, clusters with higher 
Table 1 Patient characteristics between clusters of inflammation

\begin{tabular}{|c|c|c|c|c|c|c|c|c|}
\hline & C1 & $\mathrm{C} 2$ & C3 & $\mathrm{C} 4$ & $\mathrm{C} 5$ & C6 & C7 & $p$ value \\
\hline$N$ & 2348 & 3574 & 1712 & 1014 & 1920 & 1598 & 3525 & \\
\hline Age, median [IQR] & $\begin{array}{l}71.1 \\
{[59.2-80.6]}\end{array}$ & $\begin{array}{l}66 \\
{[54.6-76.5]}\end{array}$ & $\begin{array}{l}67.3 \\
{[54.7-77.7]}\end{array}$ & $\begin{array}{l}71.6 \\
{[60.5-80.3]}\end{array}$ & $\begin{array}{l}68.4 \\
{[56.6-78.2]}\end{array}$ & $\begin{array}{l}74.6 \\
{[62-83.5]}\end{array}$ & $\begin{array}{l}76.1 \\
{[63.4-85.1]}\end{array}$ & $<0.001$ \\
\hline Gender (males), i (\%) & $1412(60.1)$ & $2469(69.1)$ & $896(52.3)$ & $734(72.4)$ & $1099(57.2)$ & $1039(65)$ & $1830(51.9)$ & $<0.001$ \\
\hline $\begin{array}{l}\text { Race, } n(\%) \\
\text { Caucasian } \\
\text { Black } \\
\text { Hispanic } \\
\text { Asian } \\
\text { Others }\end{array}$ & $\begin{array}{l}2171(92.5) \\
9(0.4) \\
140(6) \\
6(0.3) \\
22(0.9)\end{array}$ & $\begin{array}{l}3171(88.7) \\
24(0.7) \\
318(8.9) \\
20(0.6) \\
41(1.1)\end{array}$ & $\begin{array}{l}1537(89.7) \\
7(0.4) \\
138(8.1) \\
14(0.8) \\
16(0.9)\end{array}$ & $\begin{array}{l}932(91.9) \\
3(0.3) \\
66(6.5) \\
5(0.5) \\
8(0.8)\end{array}$ & $\begin{array}{l}1648(85.8) \\
9(0.5) \\
223(11.6) \\
13(0.7) \\
27(1.4)\end{array}$ & $\begin{array}{l}1458(91.2) \\
8(0.5) \\
105(6.6) \\
5(0.3) \\
22(1.4)\end{array}$ & $\begin{array}{l}3242(92) \\
17(0.5) \\
217(6.2) \\
9(0.3) \\
40(1.1)\end{array}$ & $<0.001$ \\
\hline $\begin{array}{l}\text { Days from onset to admission, } \\
\text { median [IQR] }\end{array}$ & $6[3-9]$ & $7[4-10]$ & $7[4-9]$ & $7[4-9]$ & $7[4-10]$ & $6[3-9]$ & $6[3-9]$ & $<0.001$ \\
\hline BMI, median [IQR] & 28 [25-32] & 29 [25-32] & $28[26-32]$ & 29 [26-33] & 29 [26-33] & $29[25-84]$ & 28 [25-32] & $<0.001$ \\
\hline $\begin{array}{l}\text { Smoking behavior, } n(\%) \\
\text { Never smoker } \\
\text { Former smoker } \\
\text { Current smoker }\end{array}$ & $\begin{array}{l}1604(68.3) \\
658(28) \\
86(3.7)\end{array}$ & $\begin{array}{l}2412(67.5) \\
970(27.1) \\
192(5.4)\end{array}$ & $\begin{array}{l}1190(69.5) \\
442(25.8) \\
80(4.7)\end{array}$ & $\begin{array}{l}663(65.4) \\
302(29.8) \\
49(4.8)\end{array}$ & $\begin{array}{l}1347(70.2) \\
492(25.6) \\
81(4.2)\end{array}$ & $\begin{array}{l}1046(65.5) \\
452(28.3) \\
100(6.3)\end{array}$ & $\begin{array}{l}2466(70) \\
878(24.9) \\
181(5.1)\end{array}$ & $<0.001$ \\
\hline $\begin{array}{l}\text { Degree of dependency, } n(\%) \\
\text { None or mild } \\
\text { Moderate } \\
\text { Severe }\end{array}$ & $\begin{array}{l}1958(83.4) \\
224(9.5) \\
166(7.1)\end{array}$ & $\begin{array}{l}3,156(88.3) \\
243(6.8) \\
175(4.9)\end{array}$ & $\begin{array}{l}1503(87.8) \\
130(7.6) \\
79(4.6)\end{array}$ & $\begin{array}{l}873(86.1) \\
90(8.9) \\
51(5)\end{array}$ & $\begin{array}{l}1648(85.8) \\
142(7.4) \\
130(6.8)\end{array}$ & $\begin{array}{l}1211(75.8) \\
206(12.9) \\
181(11.3)\end{array}$ & $\begin{array}{l}2558(72.6) \\
535(15.2) \\
432(12.3)\end{array}$ & $<0.001$ \\
\hline Arterial hypertension, $n(\%)$ & $1244(53)$ & $1732(48.5)$ & $831(48.5)$ & $597(58.9)$ & $1038(54.1)$ & $902(56.4)$ & $2086(59.2)$ & $<0.001$ \\
\hline Dyslipidemia, $n(\%)$ & 932 (39.7) & $1332(37.3)$ & $662(38.7)$ & $447(44.1)$ & $813(42.3)$ & $672(42.1)$ & $1500(42.6)$ & $<0.001$ \\
\hline Diabetes mellitus, $n(\%)$ & $50(22.1)$ & $609(17)$ & $287(16.8)$ & 209 (20.6) & $480(25)$ & $403(25.2)$ & $852(24.2)$ & $<0.001$ \\
\hline Atrial fibrillation, $n(\%)$ & $349(14.9)$ & $319(8.9)$ & $182(10.6)$ & $147(14.5)$ & $174(9.1)$ & $180(11.3)$ & $407(11.5)$ & $<0.001$ \\
\hline Ischemic cardiopathy, $n(\%)$ & $227(9.7)$ & $224(6.3)$ & $123(7.2)$ & $80(7.9)$ & $148(7.7)$ & $153(9.6)$ & $332(9.4)$ & $<0.001$ \\
\hline Cerebrovascular disease, $n(\%)$ & $182(7.8)$ & $216(6)$ & $113(6.6)$ & $90(8.9)$ & $124(6.5)$ & $134(8.4)$ & $326(9.2)$ & $<0.001$ \\
\hline Peripheral arterial disease, $n(\%)$ & $95(4)$ & $116(3.2)$ & $50(2.9)$ & $49(4.8)$ & $75(3.9)$ & $113(7.1)$ & $212(6)$ & $<0.001$ \\
\hline Dementia, $n(\%)$ & $221(9.4)$ & $234(6.5)$ & $126(7.4)$ & $68(6.7)$ & $150(7.8)$ & $236(14.8)$ & $596(16.9)$ & $<0.001$ \\
\hline Chronic heart failure, $n(\%)$ & $199(8.5)$ & $159(4.4)$ & $110(6.4)$ & $77(7.6)$ & $97(5.1)$ & $138(8.6)$ & $351(10)$ & $<0.001$ \\
\hline Chronic liver disease, $n(\%)$ & $88(3.7)$ & $115(3.2)$ & $60(3.5)$ & $39(3.8)$ & $50(2.6)$ & $81(5.1)$ & $132(3.7)$ & 0.008 \\
\hline Severe chronic renal failure, $n(\%)$ & $163(6.9)$ & $179(5)$ & $82(4.8)$ & $60(5.9)$ & $84(4.4)$ & $153(9.6)$ & $320(9.1)$ & $<0.001$ \\
\hline Cancer, $n(\%)$ & $280(11.9)$ & $296(8.3)$ & $150(8.8)$ & $93(9.2)$ & $142(7.4)$ & $215(13.5)$ & 419 (11.9) & $<0.001$ \\
\hline COPD, $n(\%)$ & $197(8.4)$ & $225(6.3)$ & $97(5.7)$ & $71(7)$ & $119(6.2)$ & $122(7.6)$ & $290(8.2)$ & $<0.001$ \\
\hline Asthma, $n(\%)$ & $162(6.9)$ & $224(6.3)$ & $127(7.4)$ & $52(5.1)$ & $148(7.7)$ & $90(5.6)$ & $210(6)$ & 0.022 \\
\hline OSAS, $n(\%)$ & $138(5.9)$ & $226(6.3)$ & $100(5.8)$ & $68(6.7)$ & $127(6.6)$ & $86(5.4)$ & $216(6.1)$ & 0.722 \\
\hline Charlson index median [IQR] & $1[0-2]$ & $0[0-1]$ & $0[0-2]$ & $1[0-2]$ & $1[0-2]$ & $1[0-2]$ & $1[0-2]$ & $<0.001$ \\
\hline
\end{tabular}

$B M I$ body mass index, $I Q R$ interquartile range, $C O P D$ chronic obstructive pulmonary disease, $O S A S$ obstructive sleep apnea syndrome, Severe chronic renal failure: Creatinine $>300 \mathrm{mg} / \mathrm{dl}$ or dyalisis

D-dimer elevation (C6 and C7) more frequently received high doses of LMWH.

\section{Outcomes between groups}

The clusters with the highest in-hospital mortality were C4, C6, and C7 (36.8\% vs. $39.3 \%$ vs. $26.4 \%$ ) (Table 2 ; Fig. 3). It is also noteworthy that the $\mathrm{C} 4$ cluster with a higher analytical inflammatory component is the group with the highest requirements for HFNC, NIMV, IMV, and ICU admission. On the other hand, the $\mathrm{C} 6$ and $\mathrm{C} 7$ clusters with greater prominence of D-dimer have high mortality but not so high requirements for HFNC, NIMV, IMV, and ICU admission.

\section{Risk factors for in-hospital mortality}

Table S4 shows the risk factors for in-hospital mortality. These included age $(\mathrm{OR}=1.07, p<0.001)$, female sex $(\mathrm{OR}=0.71, p<0.001)$, Black race $(\mathrm{OR}=0.19, p=0.032)$, higher BMI $(\mathrm{OR}=1.02, p<0.001)$, time from disease onset to admission $(\mathrm{OR}=0.96, p<0.001)$, higher degree 

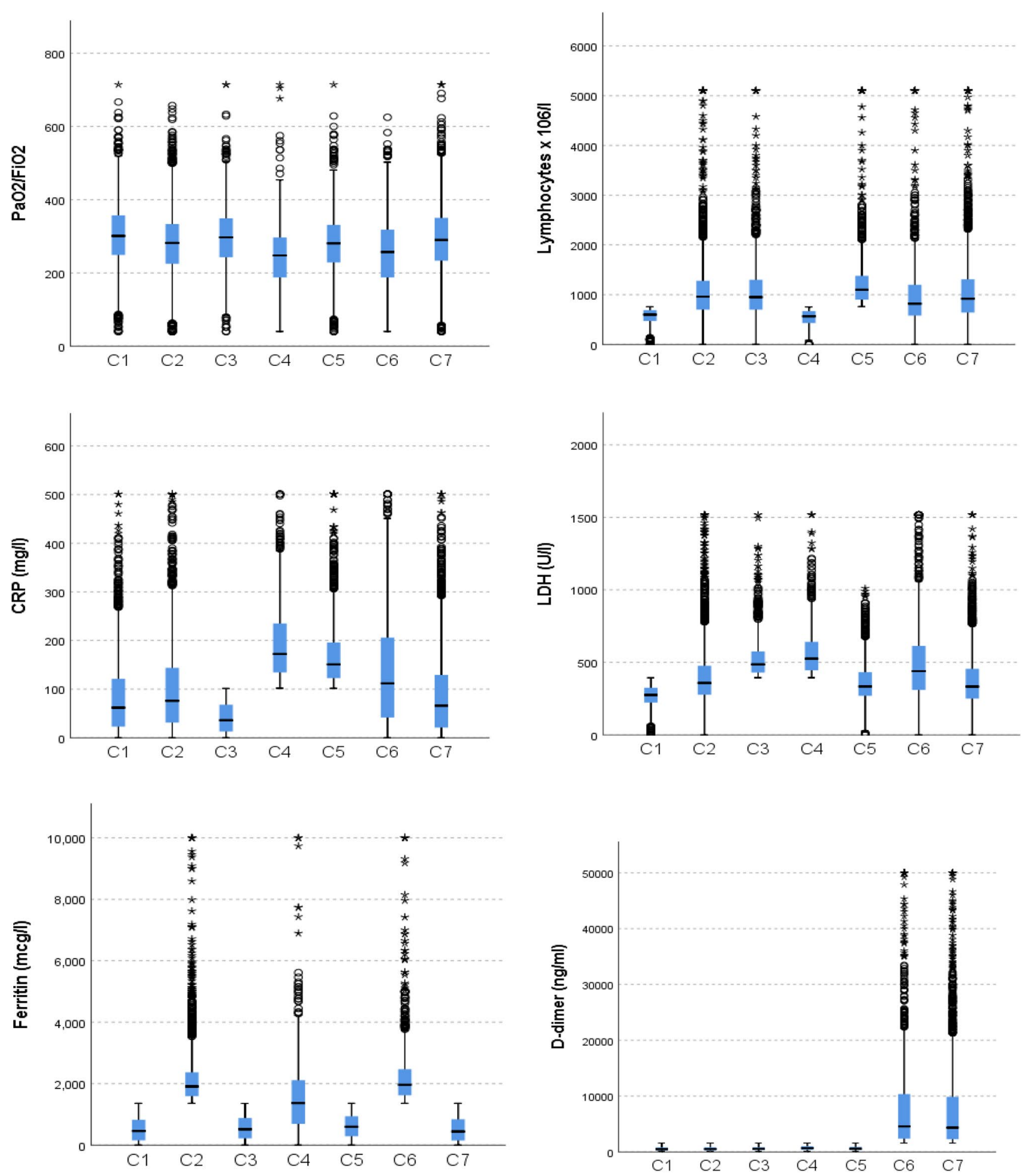

Fig. 2 Distribution of the parameters of inflammation between clusters. Mann-Whitney $U$ test ( $p<0.001$ for all parameters). Each box defines the median and the 25th and 75th percentile. The whiskers define the dispersion, the circles the outliers and the asterisks the extreme values

of dependency $(\mathrm{OR}=1.39, p<0.001$ for moderate and $\mathrm{OR}=1.66, p<0.001$ for severe), ischemic heart disease $(\mathrm{OR}=1.32, p<0.001)$, higher Charlson index $(\mathrm{OR}=1.14$, $p<0.001)$, lower $\mathrm{PaO} 2 / \mathrm{FiO} 2(\mathrm{OR}=0.99, p<0.001)$, tachypnea on admission ( $\mathrm{OR}=2.72, p<0.001)$, and inflammation clusters. In detail and, having cluster $\mathrm{C} 1$ as 
Table 2 Outcomes between clusters of inflammation

\begin{tabular}{|c|c|c|c|c|c|c|c|c|}
\hline & $\mathrm{C} 1$ & $\mathrm{C} 2$ & $\mathrm{C} 3$ & $\mathrm{C} 4$ & $\mathrm{C} 5$ & C6 & $\mathrm{C} 7$ & $p$ value \\
\hline \multicolumn{9}{|l|}{ Primary outcome $n(\%)$} \\
\hline In-hospital mortality & $408(17.4)$ & 644 (18) & $267(15.6)$ & $373(36.8)$ & $336(17.5)$ & $628(39.3)$ & $932(26.4)$ & $<0.001$ \\
\hline \multicolumn{9}{|c|}{ Secondary outcomes n (\%) } \\
\hline HFNC & $242(10.3)$ & $386(10.8)$ & $142(8.3)$ & $212(20.9)$ & $230(12)$ & $205(12.8)$ & $292(8.3)$ & $<0.001$ \\
\hline NIMV & $165(7)$ & $252(7.1)$ & $93(5.4)$ & $138(13.6)$ & $118(6.1)$ & $125(7.8)$ & $181(5.1)$ & $<0.001$ \\
\hline IMV & $142(6)$ & 344 (9.6) & $136(7.9)$ & $203(20)$ & $174(9.1)$ & $190(11.9)$ & $215(6.1)$ & $<0.001$ \\
\hline ICU admission & $213(9.1)$ & $429(12)$ & $172(10)$ & $249(24.6)$ & $229(11.9)$ & $222(13.9)$ & 277 (7.9) & $<0.001$ \\
\hline
\end{tabular}

HFNC High-flow nasal cannula, NIMV non-invasive mechanical ventilation, IMV invasive mechanical ventilation, ICU intensive care unit

Fig. 3 Kaplan-Meier curves of in-hospital mortality between clusters of inflammation. $\mathrm{C} 1$ : $17.4 \%, \mathrm{C} 2: 18 \%, \mathrm{C} 3: 15.6 \%$, C4: $36.8 \%, \mathrm{C} 5: 17.5 \%, \mathrm{C} 6$ : $39.3 \%, \mathrm{C} 7: 26.4 \% ; p<0.001$

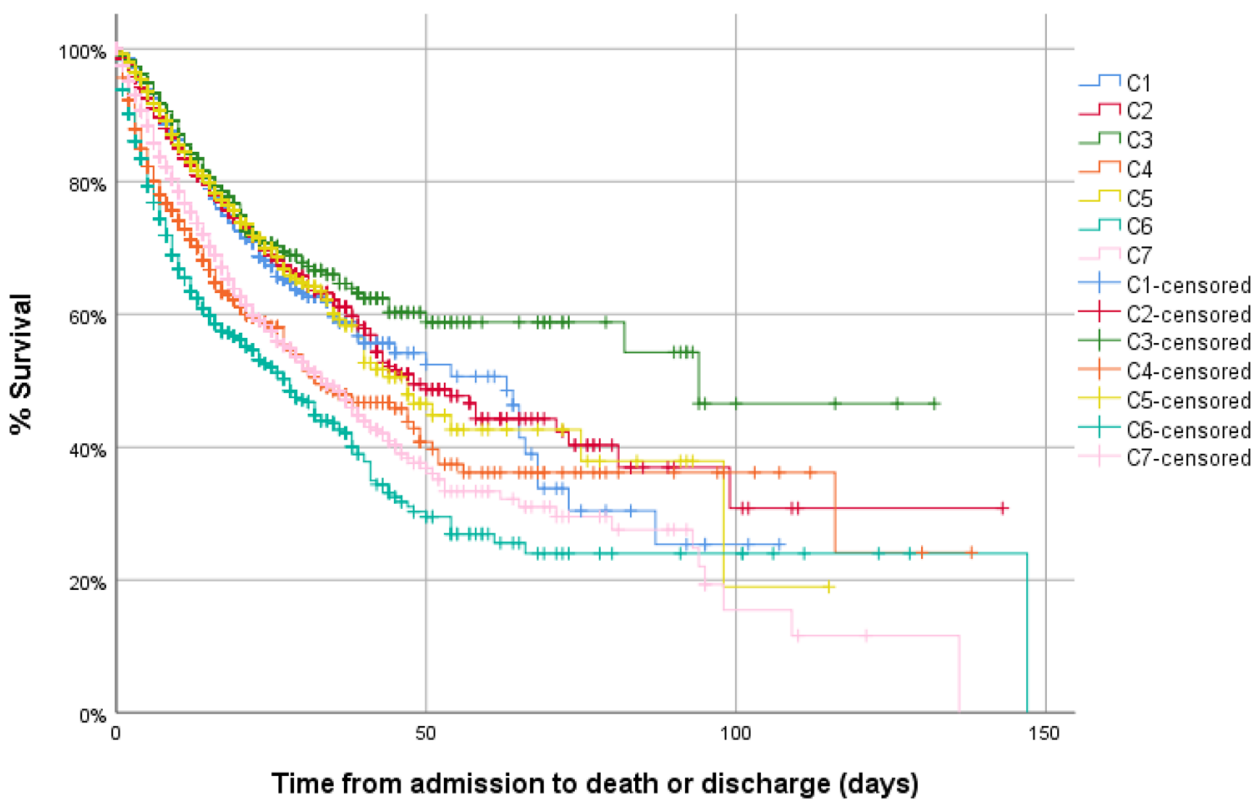

reference, the model revealed a worse prognosis for all other clusters: $\mathrm{C} 2(\mathrm{OR}=1.30, p=0.001), \mathrm{C} 3(\mathrm{OR}=1.14$, $p=0.178), \mathrm{C} 4(\mathrm{OR}=2.28, p<0.001), \mathrm{C} 5(\mathrm{OR}=1.07$, $p=0.479)$, C6 (OR=2.29, $p<0.001)$, and C7 (OR=1.28, $p=0.001$ ). The drugs received during admission (steroids, remdesivir, and tocilizumab) were included in the uni- and multivariate models due to their clinical importance and statistical influence on the rest of the variables but, despite reaching statistical significance in the multivariate model, their results must be interpreted with caution since this is not the type of study to assess their efficacy. Asthma was found to be a protective factor for in-hospital death.

\section{Discussion}

In the present study, we demonstrate the presence of 7 clearly differentiated inflammation clusters. It is clear that COVID-19 elicits an exaggerated inflammatory response but it is also clear that patients do not all become inflamed in the same way. Recently, our group had highlighted risk categories based on the degree of analytical inflammation in patients with COVID-19 at the time of hospital admission [4]. We know from that research the additive importance of such analytical inflammatory criteria. We now also know from the present study that it is important not only how many criteria the patient meets but also which ones. And this differentiation in the type of inflammation can be predicted at the time of admission. Afterward, the cascade of inflammation will continue, but the onset of inflammation already translates into differential characteristics and a very important predictive power when it comes to directing our strategies as clinicians.

The fact that the clusters with the worst prognosis $\mathrm{C} 4$, $\mathrm{C} 6$, and $\mathrm{C} 7$ are also those that occur in the older population suggests that age alone is not only a risk factor, but also that this is a population that is more inflamed. Whether this is due to a failure in the autoregulation 
of inflammatory mechanisms inherent to age should be answered with further studies. They are also clusters with higher associated comorbidity (especially $\mathrm{C} 4$ ) and one would think that those associated diseases provide an inflammatory basis that could influence. However, the C5 cluster also has considerably associated comorbidity and yet does not have as much inflammation at entry.

Inflammation clusters add to the list of factors associated with increased in-hospital mortality in COVID-19 [13-15]. All the clusters have a worse prognosis compared to cluster $\mathrm{C} 1$, which we could consider the reference cluster. However, we should focus our efforts on detecting the C4, C6, and C7 clusters first, as they are really the ones with the worst prognosis. The $\mathrm{C} 4$ cluster presents a greater inflammatory component in the form of lymphopenia, elevated CRP and $\mathrm{LDH}$, and very frequently, also elevated ferritin. It is a cluster that will evolve to acute respiratory distress syndrome (ARDS) and will require more HFNC, NIMV, IMV, and ICU admission. On the contrary, cluster C7 is a cluster with a prominence of D-dimer. It also has high mortality but clearly requires less HFNC, NIMV, IMV, and ICU admission. This could translate into higher mortality from thromboembolic disease and less progression to ARDS. Finally, cluster C6 is a mixture of clusters $\mathrm{C} 4$ and $\mathrm{C} 7$, i.e., a cluster with a prominence of D-dimer but also of ferritin and, very frequently, CRP, LDH, and lymphopenia.

Whether these 7 clusters respond to different pathways of inflammation and perhaps respond to genetic differences that condition a different host response to the same external aggression of SARS-CoV-2 is something that we cannot answer with the present study. As we have discussed previously, the inflammation cascade in patients with COVID-19 does not occur equally in all patients. In Fig. 4, we propose a logical sequence in the inflammation of these patients. It is based on the analytical characteristics of each of them and the additive possibilities. It also has a pathophysiological

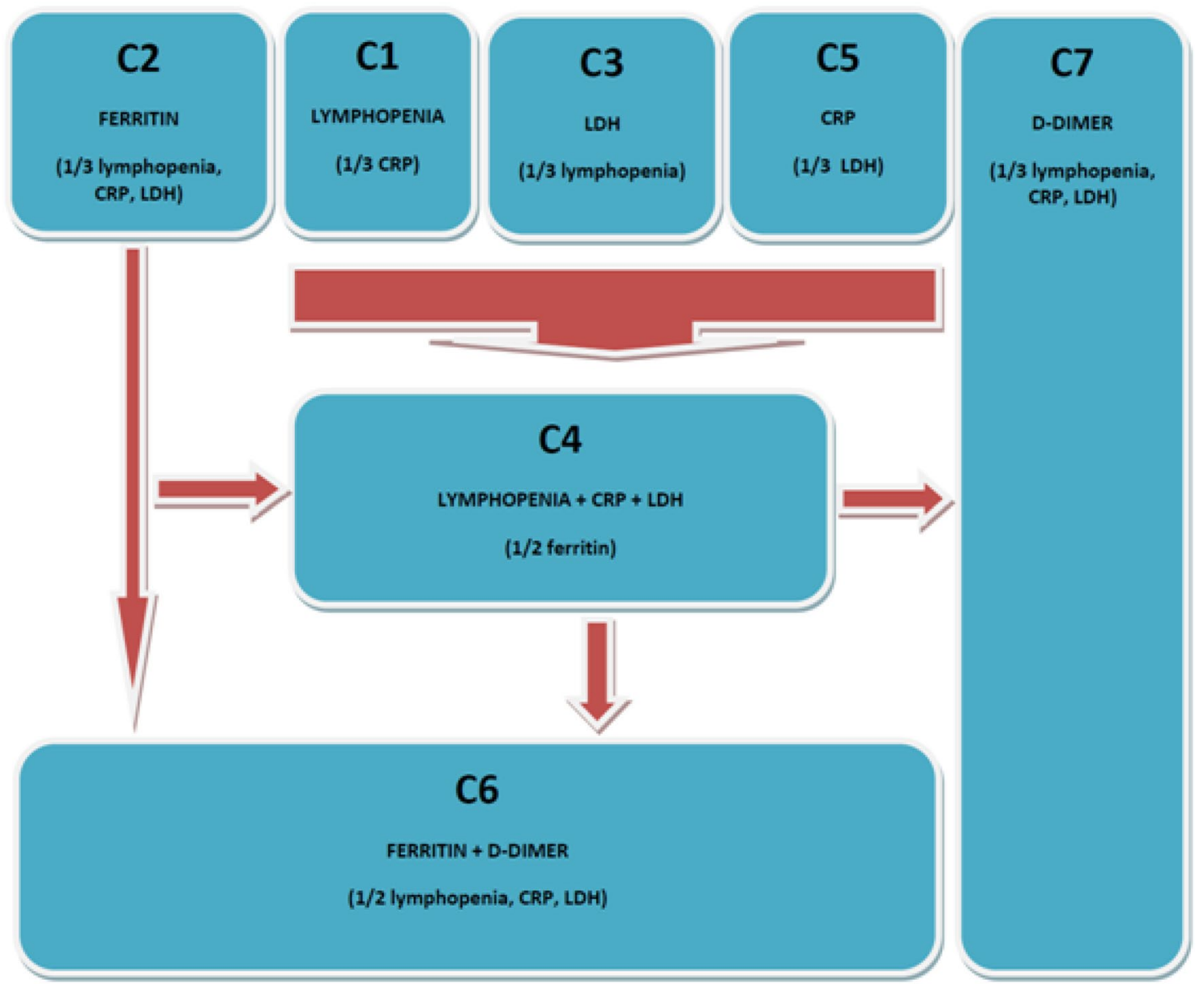

Fig. 4 Proposed algorithm for analytic inflammatory pathways in patients with COVID-19. It is based on the analytical characteristics of each of them and the additive possibilities. The initiation of the inflammatory cascade in COVID-19 is defined by macrophage activation. This includes elevation of LDH, IL6, CRP, ferritin, and cyto- penias. After this first step, vascular endothelial damage occurs and there appears the elevation of D-dimer. Cluster C7 suggests that there is a group of patients who present endothelial damage with subsequent micro- or macrothrombosis without going through a previous step of major inflammation 
logic behind it as the initiation of the inflammatory cascade in COVID-19 is defined by macrophage activation. This includes elevation of LDH, IL6, CRP, ferritin, and cytopenias. Why some patients elevate some parameters earlier and other patients elevate others is unknown. After this first step, vascular endothelial damage occurs and there appears the elevation of D-dimer.

From such a model, there are several comments to consider. First, there are 3 clusters that should sound the alarm when detected, such as clusters C4, C6, and C7. They translate more advanced stages of the disease and early action should be taken to block such escalation. On the other hand, cluster C2 does not represent such an advanced stage of inflammation but possibly the transition to cluster C6 is just around the corner in these patients (compared to clusters $\mathrm{C} 1$, $\mathrm{C} 3$, and C5 where we would have more room for maneuver). Thus, ferritin and D-dimer should be the key indicators of increased risk in patients hospitalized for COVID-19. Finally, cluster $\mathrm{C} 7$ suggests that there is a group of patients who present endothelial damage with subsequent micro- or macrothrombosis without going through a previous step of major inflammation. This is a puzzling fact that should make us rethink the doses of LMWH in patients with little inflammation.

Of all the treatments tested in COVID-19, it is the immunosuppressants/immunomodulators (corticosteroids and tocilizumab) that have demonstrated the greatest effectiveness to date [16-25]. They are especially indicated in those patients with analytical parameters of inflammation such as the patients included in the present study. However, it is plausible to think that their effectiveness is not the same in all inflammation clusters. We believe that perhaps in $\mathrm{C} 4$ (with a greater inflammatory component) and even C6 they could clearly demonstrate their benefit but perhaps in $\mathrm{C}$, with a greater role of D-dimer, they might not be so useful.

In conclusion, the present study identifies 7 inflammation groups based on the presence of lymphopenia, elevated CRP, $\mathrm{LDH}$, ferritin, and D-dimer at the time of hospital admission for COVID-19. Clusters C4 (lymphopenia + LDH + CRP), C6 (ferritin + D-dimer), and C7 (D-dimer) were the worst prognostic clusters in terms of in-hospital mortality.

\section{Appendix}

\section{List of the SEMI-COVID-19 Network members}

Coordinator of the SEMI-COVID-19 Registry: José Manuel Casas Rojo.
SEMI-COVID-19 Scientific Committee Members: José Manuel Casas Rojo, José Manuel Ramos Rincón, Carlos Lumbreras Bermejo, Jesús Millán Núñez-Cortés, Juan Miguel Antón Santos, Ricardo Gómez Huelgas.

\section{Members of the SEMI-COVID-19 Group}

H. Univ. de Bellvitge. L'Hospitalet de Llobregat (Barcelona)

Xavier Corbella, Narcís A. Homs, Abelardo Montero, Jose María Mora-Luján, Francesc Formiga, Joan AlbàAlbalate, Manuel Rubio-Rivas.

H. U. 12 de Octubre. Madrid

Paloma Agudo de Blas, Coral Arévalo Cañas, Blanca Ayuso, José Bascuñana Morejón, Samara Campos Escudero, María Carnevali Frías, Santiago Cossio Tejido, Borja de Miguel Campo, Carmen Díaz Pedroche, Raquel Diaz Simon, Ana García Reyne, Laura Ibarra Veganzones, Lucia Jorge Huerta, Antonio Lalueza Blanco, Jaime Laureiro Gonzalo, Jaime Lora-Tamayo, Carlos Lumbreras Bermejo, Guillermo Maestro de la Calle, Rodrigo Miranda Godoy, Barbara Otero Perpiña, Diana Paredes Ruiz, Marcos Sánchez Fernández, Javier Tejada Montes.

H. Costa del Sol. Marbella (Málaga)

Victoria Augustín Bandera, Javier García Alegría, Nicolás Jiménez-García, Jairo Luque del Pino, María Dolores Martín Escalante, Francisco Navarro Romero, Victoria Nuñez Rodriguez, Julián Olalla Sierra.

H. U. Gregorio Marañon. Madrid

Laura Abarca Casas, Álvaro Alejandre de Oña, Rubén Alonso Beato, Leyre Alonso Gonzalo, Jaime Alonso Muñoz, Crhistian Mario Amodeo Oblitas, Cristina Ausín García, Marta Bacete Cebrián, Jesús Baltasar Corral, Maria Barrientos Guerrero, Alejandro D. Bendala Estrada, María Calderón Moreno, Paula Carrascosa Fernández, Raquel Carrillo, Sabela Castañeda Pérez, Eva Cervilla Muñoz, Agustín Diego Chacón Moreno, Maria Carmen Cuenca Carvajal, Sergio de Santos, Andrés Enríquez Gómez, Eduardo Fernández Carracedo, María Mercedes Ferreiro-Mazón Jenaro, Francisco Galeano Valle, Alejandra Garcia, Irene Garcia Fernandez-Bravo, María Eugenia García Leoni, María Gómez Antúnez, Candela González San Narciso, Anthony Alexander Gurjian, Lorena Jiménez Ibáñez, Cristina Lavilla Olleros, Cristina Llamazares Mendo, Sara Luis García, Víctor Mato Jimeno, Clara Millán Nohales, Jesús Millán Núñez-Cortés, Sergio Moragón Ledesma, Antonio Muiño Míguez, Cecilia Muñoz Delgado, Lucía Ordieres Ortega, Susana Pardo Sánchez, Alejandro Parra Virto, María Teresa Pérez Sanz, Blanca Pinilla Llorente, Sandra Piqueras Ruiz, Guillermo Soria Fernández-Llamazares, María Toledano Macías, Neera 
Toledo Samaniego, Ana Torres do Rego, Maria Victoria Villalba Garcia, Gracia Villarreal, María Zurita Etayo.

H. de Cabueñes. Gijón (Asturias)

Ana María Álvarez Suárez, Carlos Delgado Vergés, Rosa Fernandez-Madera Martínez, Eva $\mathrm{M}^{\mathrm{a}}$ Fonseca Aizpuru, Alejandro Gómez Carrasco, Cristina Helguera Amezua, Juan Francisco López Caleya, Diego López Martínez, María del Mar Martínez López, Aleida Martínez Zapico, Carmen Olabuenaga Iscar, Lucía Pérez Casado, María Luisa Taboada Martínez, Lara María Tamargo Chamorro.

H. Reg. Univ. de Málaga

$\mathrm{M}^{\mathrm{a}}$ Mar Ayala-Gutiérrez, Rosa Bernal López, José Bueno Fonseca, Verónica Andrea Buonaiuto, Luis Francisco Caballero Martínez, Lidia Cobos Palacios, Clara Costo Muriel, Francis de Windt, Ana Teresa Fernandez-Truchaud Christophel, Paula García Ocaña, Ricardo Gómez Huelgas, Javier Gorospe García, José Antonio Hurtado Oliver, Sergio Jansen-Chaparro, Maria Dolores López-Carmona, Pablo López Quirantes, Almudena López Sampalo, Elizabeth Lorenzo-Hernández, Juan José Mancebo Sevilla, Jesica Martín Carmona, Luis Miguel Pérez-Belmonte, Iván Pérez de Pedro, Araceli Pineda-Cantero, Carlos Romero Gómez, Michele Ricci, Jaime Sanz Cánovas.

H. U. La Paz. Madrid

Jorge Álvarez Troncoso, Francisco Arnalich Fernández, Francisco Blanco Quintana, Carmen Busca Arenzana, Sergio Carrasco Molina, Aranzazu Castellano Candalija, Germán Daroca Bengoa, Alejandro de Gea Grela, Alicia de Lorenzo Hernández, Alejandro Díez Vidal, Carmen Fernández Capitán, Maria Francisca García Iglesias, Borja González Muñoz, Carmen Rosario Herrero Gil, Juan María Herrero Martínez, Víctor Hontañón, Maria Jesús Jaras Hernández, Carlos Lahoz, Cristina Marcelo Calvo, Juan Carlos Martín Gutiérrez, Monica Martinez Prieto, Elena Martínez Robles, Araceli Menéndez Saldaña, Alberto Moreno Fernández, Jose Maria Mostaza Prieto, Ana Noblejas Mozo, Carlos Manuel Oñoro López, Esmeralda Palmier Peláez, Marina Palomar Pampyn, Maria Angustias Quesada Simón, Juan Carlos Ramos Ramos, Luis Ramos Ruperto, Aquilino Sánchez Purificación, Teresa Sancho Bueso, Raquel Sorriguieta Torre, Clara Itziar Soto Abanedes, Yeray Untoria Tabares, Marta Varas Mayoral, Julia Vásquez Manau.

H. Royo Villanova. Zaragoza

Nicolás Alcalá Rivera, Anxela Crestelo Vieitez, Esther del Corral Beamonte, Jesús Díez Manglano, Isabel Fiteni Mera, Maria del Mar Garcia Andreu, Martin Gericó Aseguinolaza, Cristina Gallego Lezaun, Claudia Josa Laorden, Raul Martínez Murgui, Marta Teresa Matía Sanz.

H. Clínico de Santiago de Compostela (A Coruña)

Maria del Carmen Beceiro Abad, Maria Aurora Freire Romero, Sonia Molinos Castro, Emilio Manuel Paez Guillan, María Pazo Nuñez, Paula Maria Pesqueira Fontan.

H. Clínico San Carlos. Madrid
Inés Armenteros Yeguas, Javier Azaña Gómez, Julia Barrado Cuchillo, Irene Burruezo López, Noemí Cabello Clotet, Alberto E. Calvo Elías, Elpidio Calvo Manuel, Carmen María Cano de Luque, Cynthia Chocron Benbunan, Laura Dans Vilan, Claudia Dorta Hernández, Ester Emilia Dubon Peralta, Vicente Estrada Pérez, Santiago FernandezCastelao, Marcos Oliver Fragiel Saavedra, José Luis García Klepzig, Maria del Rosario Iguarán Bermúdez, Esther Jaén Ferrer, Alejandro Maceín Rodríguez, Alejandro Marcelles de Pedro, Rubén Ángel Martín Sánchez, Manuel Méndez Bailón, Sara Miguel Álvarez, Maria José Nuñez Orantos, Carolina Olmos Mata, Eva Orviz García, David Oteo Mata, Cristina Outon González, Juncal Perez-Somarriba, Pablo Pérez Mateos, Maria Esther Ramos Muñoz, Xabier Rivas Regaira, Laura $\mathrm{M}^{\mathrm{a}}$ Rodríguez Gallardo, Iñigo Sagastagoitia Fornie, Alejandro Salinas Botrán, Miguel Suárez Robles, Maddalena Elena Urbano, Andrea María Vellisca González, Miguel Villar Martínez.

H. Universitario Dr. Peset. Valencia

Juan Alberto Aguilera Ayllón, Arturo Artero, María del Mar Carmona Martín, María José Fabiá Valls, Maria de Mar Fernández Garcés, Ana Belén Gómez Belda, Ian López Cruz, Manuel Madrazo López, Elisabeth Mateo Sanchis, Jaume Micó Gandia, Laura Piles Roger, Adela Maria Pina Belmonte, Alba Viana García.

H. U. Puerta de Hierro. Madrid

María Álvarez Bello, Ane Andrés Eisenhofer, Ana Arias Milla, Isolina Baños Pérez, Laura Benítez Gutiérrez, Javier Bilbao Garay, Silvia Blanco Alonso, Jorge Calderón Parra, Alejandro Callejas Díaz, José María Camino Salvador, $\mathrm{M}^{\mathrm{a}}$ Cruz Carreño Hernández, Valentín Cuervas-Mons Martínez, Sara de la Fuente Moral, Miguel del Pino Jimenez, Alberto Díaz de Santiago, Itziar Diego Yagüe, Ignacio Donate Velasco, Ana María Duca, Pedro Durán del Campo, Gabriela Escudero López, Esther Expósito Palomo, Ana Fernández Cruz, Esther Fiz Benito, Andrea Fraile López, Amy Galán Gómez, Sonia García Prieto, Claudia García RodríguezMaimón, Miguel Ángel García Viejo, Javier Gómez Irusta, Edith Vanessa Gutiérrez Abreu, Isabel Gutiérrez Martín, Ángela Gutiérrez Rojas, Andrea Gutiérrez Villanueva, Jesús Herráiz Jiménez, Pedro Laguna del Estal, $M^{\mathrm{a}}$ Carmen Máinez Sáiz, Cristina Martín Martín, María Martínez Urbistondo, Fernando Martínez Vera, Susana Mellor Pita, Patricia Mills Sánchez, Esther Montero Hernández, Alberto Mora Vargas, Cristina Moreno López, Alfonso Ángel-Moreno Maroto, Victor Moreno-Torres, Concha, Ignacio Morrás De La Torre, Elena Múñez Rubio, Rosa Muñoz de Benito, Ana Muñoz Gómez, Alejandro Muñoz Serrano, Jose María Palau Fayós, Lina Marcela Parra Ramírez, Ilduara Pintos Pascual, Arturo José Ramos Martín-Vegue, Antonio Ramos Martínez, Isabel Redondo Cánovas del Castillo, Alberto Roldán Montaud, Lucía Romero Imaz, Yolanda Romero Pizarro, Enrique Sánchez Chica, David Sánchez Órtiz, Mónica 
Sánchez Santiuste, Patricia Serrano de la Fuente, Pablo Tutor de Ureta, Ángela Valencia Alijo, Mercedes ValentínPastrana Aguilar, Juan Antonio Vargas Núñez, Jose Manuel Vázquez Comendador, Gema Vázquez Contreras, Carmen Vizoso Gálvez.

H. U. Reina Sofía. Córdoba

Antonio Pablo Arenas de Larriva, Pilar Calero Espinal, Javier Delgado Lista, Francisco Fuentes-Jiménez, María del Carmen Guerrero Martínez, María Jesús Gómez Vázquez, Jose Jiménez Torres, Laura Limia Pérez, José LópezMiranda, Laura Martín Piedra, Marta Millán Orge, Javier Pascual Vinagre, Pablo Pérez-Martinez, María Elena Revelles Vílchez, Angela Rodrigo Martínez, Juan Luis Romero Cabrera, José David Torres-Peña.

C. H. U. de Badajoz

Rafael Aragon Lara, Inmaculada Cimadevilla Fernandez, Juan Carlos Cira García, Gema Maria García García, Julia Gonzalez Granados, Beatriz Guerrero Sánchez, Francisco Javier Monreal Periáñez, Maria Josefa Pascual Perez.

H. Moisès Broggi. Sant Joan Despí (Barcelona)

Judit Aranda Lobo, Lucía Feria Casanovas, Jose Loureiro Amigo, Miguel Martín Fernández, Isabel Oriol Bermúdez, Melani Pestaña Fernández, Nicolas Rhyman, Nuria Vázquez Piqueras.

H. U. Río Hortega. Valladolid

Irene Arroyo Jiménez, Marina Cazorla González, Marta Cobos-Siles, Luis Corral-Gudino, Pablo Cubero-Morais, María González Fernández, José Pablo Miramontes González, Marina Prieto Dehesa, Pablo Sanz Espinosa.

H. U. S. Juan de Alicante (Alicante)

Marisa Asensio Tomás, David Balaz, David Bonet Tur, Ruth Cañizares Navarro, Paloma Chazarra Pérez, Jesús Corbacho Redondo, Eliana Damonte White, María Escamilla Espínola, Leticia Espinosa Del Barrio, Pedro Jesús Esteve Atiénzar, Carles García Cervera, David Francisco García Núñez, Francisco Garrido Navarro, Vicente Giner Galvañ, Angie Gómez Uranga, Javier Guzmán Martínez, Isidro Hernández Isasi, Lourdes Lajara Villar, Verónica Martínez Sempere, Juan Manuel Núñez Cruz, Sergio Palacios Fernández, Juan Jorge Peris García, Rafael Piñol Pleguezuelos, Andrea Riaño Pérez, José Miguel Seguí Ripoll, Azucena Sempere Mira, Philip Wikman-Jorgensen.

H. Nuestra Señora del Prado. Talavera de la Reina (Toledo)

Sonia Casallo Blanco, Jeffrey Oskar Magallanes Gamboa, Cristina Salazar Mosteiro, Andrea Silva Asiain.

H. de Pozoblanco (Córdoba)

José Nicolás Alcalá Pedrajas, Antonia Márquez García, Inés Vargas.

H. G. U. de Elda (Alicante)

Carmen Cortés Saavedra, Jennifer Fernández Gómez, Borja González López, María Soledad Hernández Garrido,
Ana Isabel López Amorós, Santiago López Gil, Maria de los Reyes Pascual Pérez, Nuria Ramírez Perea, Andrea Torregrosa García.

H. U. Infanta Cristina. Parla (Madrid)

Juan Miguel Antón Santos, Ana Belén Barbero Barrera, Blanca Beamonte Vela, Coralia Bueno Muiño, Charo Burón Fernández, Ruth Calderón Hernáiz, Irene Casado López, José Manuel Casas Rojo, Andrés Cortés Troncoso, Pilar Cubo Romano, Francesco Deodati, Alejandro Estrada Santiago, Gonzalo García Casasola Sánchez, Elena García Guijarro, Francisco Javier García Sánchez, Pilar García de la Torre, Mayte de Guzmán García-Monge, Davide Luordo, María Mateos González, José A. Melero Bermejo, Cruz Pastor Valverde, José Luis Pérez Quero, Fernando Roque Rojas, Lorea Roteta García, Elena Sierra Gonzalo, Francisco Javier Teigell Muñoz, Juan Vicente de la Sota, Javier Villanueva Martínez.

\section{H. Santa Marina. Bilbao}

María Areses Manrique, Ainara Coduras Erdozain, Ane Labirua-Iturburu Ruiz.

H. San Pedro. Logroño (La Rioja)

Diana Alegre González, Irene Ariño Pérez de Zabalza, Sergio Arnedo Hernández, Jorge Collado Sáenz, Beatriz Dendariena, Marta Gómez del Mazo, Iratxe Martínez de Narvajas Urra, Sara Martínez Hernández, Estela Menendez Fernández, Jose Luís Peña Somovilla, Elisa Rabadán Pejenaute.

H. U. Son Llàtzer. Palma de Mallorca

Andrés de la Peña Fernández, Almudena Hernández Milián.

C. H. U. Ourense

Raquel Fernández González, Amara Gonzalez Noya, Carlos Hernández Ceron, Isabel Izuzquiza Avanzini, Ana Latorre Diez, Pablo López Mato, Ana María Lorenzo Vizcaya, Daniel Peña Benítez, Milagros María Peña Zemsch, Lucía Pérez Expósito, Marta Pose Bar, Lara Rey González, Laura Rodrigo Lara.

H. U. La Fe. Valencia

Dafne Cabañero, María Calabuig Ballester, Pascual Císcar Fernández, Ricardo Gil Sánchez, Marta Jiménez Escrig, Cristina Marín Amela, Laura Parra Gómez, Carlos Puig Navarro, José Antonio Todolí Parra.

H. de Mataró. Barcelona

Raquel Aranega González, Ramon Boixeda, Javier Fernández Fernández, Carlos Lopera Mármol, Marta Parra Navarro, Ainhoa Rex Guzmán, Aleix Serrallonga Fustier.

H. de Sagunto (Valencia)

Enrique Rodilla Sala, Jose María Pascual Izuel, Zineb Karroud Zamrani.

H. Alto Guadalquivir. Andújar (Jaén)

Begoña Cortés Rodríguez.

C. H. U. de Ferrol (A Coruña) 
Hortensia Alvarez Diaz, Tamara Dalama Lopez, Estefania Martul Pego, Carmen Mella Pérez, Ana Pazos Ferro, Sabela Sánchez Trigo, Dolores Suarez Sambade, Maria Trigas Ferrin, Maria del Carmen Vázquez Friol, Laura Vilariño Maneiro.

H. Infanta Margarita. Cabra (Córdoba)

María Esther Guisado Espartero, Lorena Montero Rivas, Maria de la Sierra Navas Alcántara, Raimundo Tirado-Miranda.

H. Público de Monforte de Lemos (Lugo)

José López Castro, Manuel Lorenzo López Reboiro, Cristina Sardiña González.

H. U. Virgen del Rocío. Sevilla

Reyes Aparicio Santos, Máximo Bernabeu-Wittel, Santiago Rodríguez Suárez, María Nieto, Luis Giménez Miranda, Rosa María Gámez Mancera, Fátima Espinosa Torre, Carlos Hernandez Quiles, Concepción Conde Guzmán, Juan Delgado de la Cuesta, Jara Eloisa Ternero Vega, María del Carmen López Ríos, Pablo Díaz Jiménez, Bosco Baron Franco, Carlos Jiménez de Juan, Sonia Gutiérrez Rivero, Julia Lanseros Tenllado, Verónica Alfaro Lara, Aurora González Estrada.

H. Marina Baixa. Villajoyosa (Alicante)

Javier Ena, José Enrique Gómez Segado.

C. A. U. de Salamanca

Gloria María Alonso Claudio, Víctor Barreales Rodríguez, Cristina Carbonell Muñoz, Adela Carpio Pérez, María Victoria Coral Orbes, Daniel Encinas Sánchez, Sandra Inés Revuelta, Miguel Marcos Martín, José Ignacio Martín González, José Ángel Martín Oterino, Leticia Moralejo Alonso, Sonia Peña Balbuena, María Luisa Pérez García, Ana Ramon Prados, Beatriz Rodríguez-Alonso, Ángela Romero Alegría, Maria Sanchez Ledesma, Rosa Juana Tejera Pérez.

H. General Defensa. Zaragoza

Anyuli Gracia Gutiérrez, Leticia Esther Royo Trallero. H. de Palamós (Girona)

Ana Alberich Conesa, Mari Cruz Almendros Rivas, Miquel Hortos Alsina, José Marchena Romero, Anabel Martin-Urda Diez-Canseco.

H. Comarcal de Blanes (Girona)

Oriol Alonso Gisbert, Mercé Blázquez Llistosella, Pere Comas Casanova, Angels Garcia Flores, Anna Garcia Hinojo, Ana Inés Méndez Martínez, Maria del Carmen Nogales Nieves, Agnés Rivera Austrui, Alberto Zamora Cervantes.

H. do Salnes. Vilagarcía de Arousa (Pontevedra)

Vanesa Alende Castro, Ana María Baz Lomba, Ruth Brea Aparicio, Marta Fernández Morales, Jesús Manuel Fernández Villar, María Teresa López Monteagudo, Cristina Pérez García, Lorena Rodríguez Ferreira, Diana Sande Llovo, Maria Begoña Valle Feijoo.
H. U. HM Montepríncipe

José F. Varona Arche.

Supplementary Information The online version contains supplementary material available at https://doi.org/10.1007/s11739-021-02924-4.

Acknowledgements We gratefully acknowledge all the investigators who participate in the SEMI-COVID-19 Registry. We also thank the SEMI-COVID-19 Registry Coordinating Center for their quality control data, logistic and administrative support.

Funding This research did not receive any specific grant from funding agencies in the public, commercial, or not-for-profit sectors.

\section{Declarations}

Conflict of interest The authors declare they have no conflict of interest.

Statement of human and animal rights The study has been approved by the ethics committee of Bellvitge University Hospital.

Informed consent Informed consent was obtained from the subjects.

Authorship All authors had access to the data and a role in writing this manuscript.

\section{References}

1. https://coronavirus.jhu.edu/map.html

2. B Hu S Huang L Yin 2021 The cytokine storm and COVID-19 J Med Virol 93250256

3. LZ Hong ZX Shou DM Zheng X Jin 2021 The most important biomarker associated with coagulation and inflammation among COVID-19 patients Mol Cell Biochem 47619

4. M Rubio-Rivas X Corbella F Formiga 2021 Risk categories in COVID-19 based on degrees of inflammation. Data on more than 17,000 patients from the Spanish SEMI-COVID-19 registry J Clin Med 102214 Epub ahead of print

5. JM Casas-Rojo JM Antón-Santos J Millán-Núñez-Cortés 2020 Clinical characteristics of patients hospitalized with COVID-19 in Spain: results from the SEMI-COVID-19 Registry Rev Clin Esp 220480494

6. P Gautret JC Cagier P Parola 2020 Hydroxychloroquine and azithromycin as a treatment of COVID-19: results of an openlabel non-randomized clinical trial Int J Antimicrob Agents 56 105949

7. B Cao Y Wang D Wen 2020 A Trial of Lopinavir-Ritonavir in adults hospitalized with severe Covid-19 N Engl J Med 3821787 1799

8. J Grein N Ohmagari D Shin 2020 Compassionate use of remdesivir for patients with severe Covid-19 N Engl J Med 3822327 2336

9. R Capra N Rossi De F Mattioli 2020 Impact of low dose tocilizumab on mortality rate in patients with COVID-19 related pneumonia Eur J Intern Med 763135

10. C Campochiaro E Della-Torre G Cavalli 2020 Efficacy and safety of tocilizumab in severe COVID-19 patients: a single-centre retrospective cohort study Eur J Intern Med 764349 
11. A Recovery Collaborative Group P Horby WS Lim 2020 Dexamethasone in hospitalized patients with Covid-19 N Engl J Med 384693704

12. Husson F, Josse J, Pagès J (2010) Principal component methods - hierarchical clustering - partitional clustering: why would we need to choose for visualizing data? Technical Report. http://math. agrocampus-ouest.fr/infoglueDeliverLive

13. F Zhou T Yu R Du 2020 Clinical course and risk factors for mortality of adult inpatients 434 with COVID-19 in Wuhan, China: a retrospective cohort study Lancet 39510541062

14. E Rodilla MD López-Carmona X Cortes 2021 Impact of arterial stiffness on all-cause mortality in patients hospitalized with COVID-19 in Spain Hypertension 77856867

15. M Rubio-Rivas X Corbella JM Mora-Luján 2020 Predicting clinical outcome with phenotypic clusters in COVID-19 pneumonia: an analysis of 12,066 hospitalized patients from the Spanish registry SEMI-COVID-19 J Clin Med 93488

16. RECOVERY Collaborative Group P Horby WS Lim JR Emberson 2021 Dexamethasone in hospitalized patients with Covid-19 N Engl J Med 384693704

17. M Rubio-Rivas M Ronda A Padulles 2020 Beneficial effect of corticosteroids in preventing mortality in patients receiving tocilizumab to treat severe COVID-19 illness Int J Infect Dis 101290 297

18. AC Gordon PR Mouncey F Al-Beidh REMAP-CAP Investigators 2021 Interleukin- 6 receptor antagonists in critically Ill patients with Covid-19 N Engl J Med 38414911502

19. RECOVERY Collaborative Group 2021 Tocilizumab in patients admitted to hospital with COVID-19 (RECOVERY): a randomised, controlled, open-label, platform trial Lancet 3971637 1645

20. IM Tleyjeh Z Kashour M Riaz L Hassett VC Veiga T Kashour 2021 Efficacy and safety of tocilizumab in COVID-19 patients: a living systematic review and meta-analysis-first update Clin Microbiol Infect 271076

21. M Rubio-Rivas JM Mora-Luján A Montero 2021 The use of corticosteroids or tocilizumab in COVID-19 based on inflammatory markers J Gen Intern Med 1818 https://doi.org/10.1007/s11606021-07146-0 Epub ahead of print. PMID: 34664188; PMCID: PMC8523009

22. A Muñoz-Gómez A Fernández-Cruz C Lavilla-Olleros 2021 Real-life impact of glucocorticoid treatment in COVID-19 mortality: a multicenter retrospective study J Clin Med 10204678 https://doi.org/10.3390/jcm10204678 PMID: 34682801; PMCID: PMC8540860

23. D Balaz PE Wikman-Jorgensen VG Galvañ 2021 Evolution of the use of corticosteroids for the treatment of hospitalised COVID19 patients in spain between march and november 2020: SEMICOVID National Registry J Clin Med 10194610 https://doi.org/ 10.3390/jcm10194610 PMID:34640628; PMCID:PMC8509849

24. JM Mora-Luján M Tuells A Montero 2021 High-dose methylprednisolone pulses for 3 days vs. low-dose dexamethasone for 10 days in severe, non-critical COVID-19: a retrospective propensity score matched analysis J Clin Med 10194465 https://doi.org/10.3390/ jcm10194465 PMID: 34640481; PMCID: PMC8509662

25. M Rubio-Rivas CG Forero JM Mora-Luján 2021 Beneficial and harmful outcomes of tocilizumab in severe COVID-19: a systematic review and meta-analysis Pharmacotherapy 4111884 906 https://doi.org/10.1002/phar.2627 Epub 2021 Oct 1 PMID: 34558742

Publisher's Note Springer Nature remains neutral with regard to jurisdictional claims in published maps and institutional affiliations.

\section{Authors and Affiliations}

\section{Manuel Rubio-Rivas ${ }^{1}\left[\right.$ • José María Mora-Luján ${ }^{1}$ · Francesc Formiga ${ }^{1} \cdot$ Miguel Ángel Corrales González $^{2} \cdot$ María del $^{5}$ Mar García Andreu ${ }^{3}$. Víctor Moreno-Torres ${ }^{4} \cdot$ Gema María García García ${ }^{5}$ · José N Alcalá Pedrajas ${ }^{6} \cdot$ Ramon Boixeda $^{7}$. Leticia Pérez-Lluna $^{8}$ - Begoña Cortés-Rodríguez ${ }^{9}$ - Carmen Mella-Pérez ${ }^{10}$ - María de la Sierra Navas Alcántara ${ }^{11}$. Manuel Lorenzo López Reboiro ${ }^{12}$. Verónica Alfaro-Lara ${ }^{13}$. Santiago Pérez-Martín ${ }^{14}$. José Ángel Martín-Oterino ${ }^{15}$. Anyuli Gracia Gutiérrez ${ }^{16}$. Anabel Martín-Urda Díez-Canseco ${ }^{17}$. Pere Comas Casanova ${ }^{18}$. Cristina Pérez García ${ }^{19}$. José $\mathrm{F}$ Varona ${ }^{20,21}$ - Ricardo Gómez-Huelgas ${ }^{22,23}$. Juan-Miguel Antón-Santos ${ }^{24}$. Carlos Lumbreras-Bermejo ${ }^{25}$ on behalf of the SEMI-COVID-19 Network}

\author{
José María Mora-Luján \\ jmora@bellvitgehospital.cat \\ Francesc Formiga \\ fformiga@bellvitgehospital.cat \\ Miguel Ángel Corrales González \\ Dr.corralesg@gmail.com \\ María del Mar García Andreu \\ mariadelmargarciaandreu@gmail.com \\ Víctor Moreno-Torres \\ victor.moreno.torres.1988@gmail.com \\ Gema María García García \\ geminway21@hotmail.com \\ José N Alcalá Pedrajas \\ Jnalcala58@hotmail.com
}

Ramon Boixeda

Rboixeda@csdm.cat

Leticia Pérez-Lluna

doctoraperezlluna@gmail.com

Begoña Cortés-Rodríguez

begocortesrod@gmail.com

Carmen Mella-Pérez

mellacarmen@gmail.com

María de la Sierra Navas Alcántara

maria.sierra.navas@gmail.com

Manuel Lorenzo López Reboiro

manuel.lorenzo.lopez.reboiro@sergas.es

Verónica Alfaro-Lara

valfarolara@hotmail.com 
Santiago Pérez-Martín

santino_perez@hotmail.com

José Ángel Martín-Oterino

jmoterino@saludcastillayleon.es

Anyuli Gracia Gutiérrez

agraciagut@gmail.com

Anabel Martín-Urda Díez-Canseco

anabelmartinurda10canseco@gmail.com

Pere Comas Casanova

23575pcc@comb.cat

Cristina Pérez García

saraaloe@hotmail.com

José F Varona

jfvarona@hmhospitales.com

Ricardo Gómez-Huelgas

ricardogomezhuelgas@ hotmail.com

Juan-Miguel Antón-Santos

jmanton.hugf@salud.madrid.org

Carlos Lumbreras-Bermejo

clumbrerasb@gmail.com

1 Department of Internal Medicine, Bellvitge University Hospital, Bellvitge Biomedical Research Institute-IDIBELL, University of Barcelona, L'Hospitalet de Llobregat, 08907 Barcelona, Spain

2 Department of Internal Medicine, Costa del Sol Hospital. Marbella, Málaga, Spain

3 Department of Internal Medicine, Royo Villanova Hospital, Zaragoza, Spain

4 Department of Internal Medicine, Puerta de Hierro University Hospital, Majadahonda, Madrid, Spain

5 Department of Internal Medicine, Badajoz University Hospital, Badajoz, Spain

6 Department of Internal Medicine, Pozoblanco Hospital. Pozoblanco, Córdoba, Spain

7 Department of Internal Medicine, Mataró Hospital, Barcelona, Spain

8 Department of Internal Medicine, Sagunto Hospital. Sagunto, Valencia, Spain
9 Department of Internal Medicine, Alto Guadalquivir Hospital. Andújar, Jaén, Spain

10 Department of Internal Medicine, Ferrol Clinical University Hospital, El Ferrol, La Coruña, Spain

11 Department of Internal Medicine, Infanta Margarita Hospital. Cabra, Córdoba, Spain

12 Department of Internal Medicine, Monforte de Lemos Hospital, Monforte de Lemos, Lugo, Spain

13 Department of Internal Medicine, Vírgen del Rocío University Hospital, Sevilla, Spain

14 Department of Internal Medicine, Marina Baixa Hospital, Villajoyosa, Alicante, Spain

15 Department of Internal Medicine, Salamanca University Hospital, Salamanca, Spain

16 Department of Internal Medicine, Defense General Hospital, Zaragoza, Spain

17 Department of Internal Medicine, Palamós Hospital. Palamós, Girona, Spain

18 Department of Internal Medicine, Blanes Hospital, Blanes, Spain

19 Department of Internal Medicine, Do Salnes Hospital, Vilagarcía de Arousa, Pontevedra, Spain

20 Department of Internal Medicine, HM Montepríncipe University Hospital, Madrid, Spain

21 School of Medicine, San Pablo University-CEU, Madrid, Spain

22 Department of Internal Medicine, Málaga Regional University Hospital, Biomedical Research Institute of Málaga (IBIMA), University of Málaga (UMA), Málaga, Spain

23 CIBER Obesidad Y Nutricion (CIBERobn), ISCIII, Madrid, Spain

24 Department of Internal Medicine. Infanta, Cristina University Hospital, Parla, Madrid, Spain

25 Department of Internal Medicine, 12 de Octubre University Hospital, Madrid, Spain 